A Selection of the Titles in the Historical Series Published by E. \& S. Livingstone Ltd.

\title{
ESSAYS ON THE FIRST HUNDRED YEARS OF ANAESTHESIA
}

W. Stanley Sykes, M.B.E., M.A., B.Chir.(Cantab.), D.A.

$\begin{array}{llll}\text { Volume I } & 171 \text { pages } & 68 \text { illustrations } & 30 s . \\ \text { Volume II } & 192 \text { pages } & 64 \text { illustrations } & 30 s .\end{array}$

MEDICINE AND THE NAVY 1200-1900

By JohN J. KeEviL, D.S.O., J.P., M.A., M.D.

Vol. I $\cdot 1200-1649267$ pages 16 illustrations 40 s.

Vol. II 1649-1714 344 pages 20 illustrations 40s.

By Christopher Lloyd, F.R.Hist.S., and JACK L. S. COULTER, F.R.C.S.

Vol. III 1714-1815 414 pages 16 illustrations 50 s.

\section{A SHORT HISTORY OF CLINICAL PATHOLOGY \\ 166 pages \\ W. D. Foster, M.D. Cantab. 32 illustrations 27s. $6 d$.}

Please send for the full range of titles in this series

E. \& S. LIVINGSTONE LTD

TEVIOT PLACE

EDINBURGH

\section{Medical History}

BACK ISSUES

The following numbers are available:

Volume 1. Nos. 1, 3, and 4.

Volume 2. Nos. 1, 2, and 3.

Volume 3. Nos. 2, 3, and 4.

Volume 4. Nos. 1, 2, 3, and 4.

Price £1 each

from

DAWSONS

OF PALL MALL

16 Pall Mall, London, S.W.1
Rare and Important Books

Illustrating the

History of Science

AND Medicine

Biographies and Autograph

LETTERS OF SCIENTISTS AND

Medical Men

Catalogues on above subjects free on application

Hugh OK. Elliott $\mathcal{L}_{\text {td }}$ P.O. BOX 284

199 PICCADILLY

LONDON, W.1

Telephone: CUNningham 0724

Business by post or appointment only 


\section{S C H U M A N}

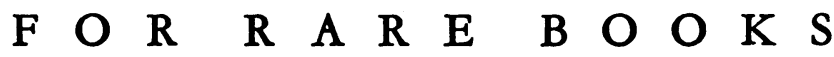
in the

\section{History of Medicine and Science}

SPECIALIZED EXPERIENCE AND CAREFUL ATTENTION GIVEN TO THE BUILDING OF COLLECTIONS IN THE HISTORY OF MAJOR MEDICAL SPECIALITIES:

CARDIOLOGY, DENTISTRY, GYNAECOLOGY, OBSTETRICS, ORTHOPAEDICS, PSYCHIATRY, PSYCHOANALYSIS, UROLOGY, ETC.

\section{SEND US YOUR DESIDERATA}

WE ARE ALWAYS GLAD TO PURCHASE ENTIRE COLLECTIONS OR SINGLE ITEMS OF MERIT

Henry Schuman Ltd, 22 I I Broadway, New York 24 CABLE ADDRESS: SCHUBOOKS 


\section{Dawsons of Pall Mall}

Forthcoming publications

A BIO-BIBLIOGRAPHY
OF FLORENCE NIGHTINGALE by

W. J. BISHOP

$300 \mathrm{pp}$.

illus.

$45 \mathrm{~s}$.

summer/autumn

\section{DISEASE and DESTINY}

A Bibliography of Medical References to the Famous by the late

JUDSON BENNETT GILBERT, M.D., F.A.C.S.

$560 \mathrm{pp}$.

$£ 6$ summer/autumn

\section{SIR JOHN TOMES}
A Pioneer of British Dentistry
by

SIR ZACHARY COPE

104 pp. illus.

summer/autumn

\section{Pall Mall, London, S.W.1}

